\title{
Effects of a Task-Based Approach to Non-English-Majored Graduates' Oral English Performance
}

\author{
Yougen Lou', Ping Chen ${ }^{2}$, Liyou Chen ${ }^{3 *}$ \\ ${ }^{1}$ School of Foreign Studies, Yangtze University, Jingzhou, China \\ ${ }^{2}$ School of Physics and Optoelectronic Engineering, Yangtze University, Jingzhou, China \\ ${ }^{3}$ Haikou Council for the Promotion of Youth Entrepreneurship and Employment, Haikou, China \\ Email: "louyougen@163.com
}

Received 24 March 2016; accepted 19 April 2016; published 22 April 2016

Copyright (C) 2016 by authors and Scientific Research Publishing Inc.

This work is licensed under the Creative Commons Attribution International License (CC BY).

http://creativecommons.org/licenses/by/4.0/

(c) () D Den Access

\begin{abstract}
The present study investigated the effects of task-based language teaching (TBLT) and learning on non-English-majored graduates' oral performance through two tasks in a comparative way. There were 65 first-year non-English-majored graduates from Yangtze University participated in this study. In this study, the experimental group was treated under the task-based language teaching (TBLT) instruction and the control group received the treatment of 3Ps instruction through one semester. At the end of the semester, two tasks were used to elicit the participants' performance. By comparing the experimental effects of task-based language teaching (TBLT) on non-Englishmajored graduates' oral performance of accuracy, fluency and complexity with that of 3Ps instruction, results in this study showed that 1) under the task-based language teaching (TBLT) instruction, there was greater accuracy for non-English-majored graduates in oral English performance; 2) under the task-based language teaching (TBLT) conditions, there was greater fluency (fewer repetitions, fewer pauses) in oral English performance; 3) under the task-based language teaching (TBLT) instruction, there was greater complexity (a greater number of words per AS-unit.) in oral English performance. The author drew a conclusion that TBLT methodology was superior to that of 3Ps.
\end{abstract}

\section{Keywords}

Task-Based Language Teaching, Non-English-Majored Graduates, Oral Performance

\section{Introduction}

Task-based language teaching (TBLT) and learning and emerged in the early 1980s and is currently considered

${ }^{*}$ Corresponding author. 
as one of the most effective approaches to language teaching and learning (Dettori \&Giuliana, 2011). Experiments on task-based language teaching (TBLT) in higher education have sprung up in China. As far as the author knows, task-based learning and teaching has not been fully established in colleges or universities in China and is generally considered - except by younger or more recently trained teachers - to be innovative. Teachers need the evidence of successful examples of the implementation of TBLT to support that TBLT is beneficial to language learners. Thus, it is worthwhile studying the effect in colleges or universities, either for a practical rationale in China or for a theoretical justification to enable TBLT to be better understood. However, few studies related to TBLT on non-English-majored graduates have been found now.

The present study was to investigate the effects of TBLT on non-English-majored graduates' oral performance of accuracy, fluency and complexity in a comparative way from the following questions:

1) Under TBLT instruction, will there be greater accuracy (a lower proportion of errors to total words) for non-English-majored graduates in oral English performance?.

2) Under TBLT conditions, will there be greater fluency (fewer repetitions, fewer pauses) in oral English performance?

3) Under TBLT instruction, will there be greater complexity (a greater number of words per AS-unit.) in oral English performance?

\section{Literature Review}

\subsection{The Definition of Task}

Task is defined in various ways. Nunan (2004) offers his own definition: [A] pedagogic task is a piece of classroom work that involves the learner in comprehending, manipulating, producing or interacting in the target language while their attention is focused on mobilizing their grammatical knowledge in order to express meaning, and in which the intention is to convey meaning rather than to manipulate form. The task should also have a sense of completeness, being able to stand alone as a communicative act in its own right with a beginning, middle and an end (p. 4). Skehan (1996a) states that task is an activity in which: meaning is prior to form; there is source sort of relationship to the real world; tasks are problem-oriented; the outcome is the index for assessment of task performance. Ellis (2003) pointed out that Skehan's definition was made from a researcher's point of view rather than from the learners' point of view. Nunan (1989) regarded the communicative task as an example of meaning-based activities, which involved learners in using the target language to serve different communicative purposes. So it is clear that Nunan's (1989) definition of task stems largely from communicative language teaching. Willis points out that "tasks are activities in which learners use the target language for a communicative purpose (goal) to achieve an outcome” (Willis, 1996a: p. 23). In other words, tasks are the activities in which learners use whatever target language resources they have in order to solve a problem, do a puzzle, play a game or share and compare experiences (ibid.). Willis's (1996a) definition of tasks is adopted in this study.

\subsection{Task-Based Language Teaching}

A lot of researchers were interested in task-based language teaching and learning approach in the world.

Robertson, Margaret (2014) explained the congruence between TBLT and expansive learning theory and the benefits of doing so. Huang, Jiuhan (2010) outlined the 10 principles of instructed language learning formulated by Ellis and showed how using Willis' Task-Based Learning Framework in grammar instruction for adults responses to many of the 10 principles.

In China, there were some researchers interested in the task-based language teaching and learning approach. Zhaochun Sun (2015) reported a tentative study on the task-based teaching of writing to English majors in Chinese settings and Sun found the findings of this research reveal that the application of TBL framework to English writing classrooms in Chinese EFL settings is effective in improving English majors' writing competence and performance. Ji (2014) reported effects of a task-based approach to public speaking instruction and concluded that task-based instruction supported learner-initiated learning opportunities outside the classroom, thus encouraging greater learner improvements.

\subsection{Task-Based Language Teaching (TBLT) Framework and, Presentation, Practice and Production (3P) Framework}

Over the past decade or so, various frameworks for implementing TBLT in the classroom have been proposed 
(Ellis, 2003; Skehan, 1996a, 1996b; Willis, 1996a). Although these frameworks vary a bit in their terms, they all share three principal phases named pre-task, while task and post task. This study adopted Willis's (1996a) framework, which is showed in Table 1, for implementing TBLT in experimental group.

According to Skehan (1996a), "3Ps" approach is regarded as one of the comparative approach towards TBLT. It gains people's attention when they discuss the implementation of TBLT. The present study attempts to find out the effect of TBLT in comparison with that of 3Ps on learners' oral performance. Thus, this study used the framework of 3Ps approach (Baker \& Westrup, 2003), illustrated in Table 2, in control group.

\subsection{The Differences between TBLT and 3Ps}

According to the related studies, TBLT and 3Ps differ mainly in two ways.

First of all, there is different order of form and meaning in each framework. Willis (1996b) argued that in 3Ps cycle, focus on form comes first and focus on meaning comes later. On the contrary, in the TBLT framework, the order is reversed. What's more, the views on two pedagogues' goals namely accuracy and fluency, are different. Willis concluded that "3Ps is based on the assumption that out of accuracy comes fluency. This methodology entails a good deal of language control on the part of the teacher in the interest of accuracy” (1996b:45). However, Willis (1996b) explained that TBLT is based on the assumption that out of fluency comes accuracy. The implementation of this methodology is through a deep-end strategy whereby learners do their best to achieve some kind of resolution to a communicative problem through the effective use of their existing language resources.

\subsection{The Study of Second Language Performance of Accuzracy, Fluency and Complexity}

Most of the relevant empirical studies into tasks lie in the three pedagogic goals for task-based approaches: accuracy, complexity and fluency. It is Skehan's (1996a, 1996b, 1998) three-aspect distinction between fluency, accuracy and complexity of linguistic performance that form the basis for measuring learners' language production in task-based related research. Skehan (1998) listed three areas as follows: a) meaning which is reflected in fluency; b) form-control, reflected in accuracy; c) form-restructuring which is related to the complexity of the language. Skehan concluded that three pedagogicgoals "are also effective indices for measuring performance on a particular task and, in this way, provide a method for assessing the worth of different tasks” (1998: 270).

Task performance provides clues to discover the function of tasks in promoting language acquisition as well as the challenge a task imposes on learners. It can be observed both qualitatively and quantitatively. Qualitative observation concerns general tendencies of linguistic performance to which a task may be related. The quantitative observation mainly concerns the commonly observed aspects of linguistic performance, such as accuracy, fluency, complexity and appropriacy. Besides the qualitative nature of task related performances, many researchers are concerned with task-related performance in the form of linguistic complexity, accuracy and fluency. Skehan (1996a, 1998) argued that these measures are considered theoretically related to the development of

\section{Table 1. Willis’s (1996a) task-based language teaching framework.}

Phases

Longer pre-task

Task cycle

Language focus
Main activities in each phase

Introduction to topic and task

More sets of short tasks, followed by lots of teacher chat about the tasks. Gradual increase I emphasis on Planning \& Report.

Analysis practice

Table 2. The framework of presentation, practice and production.

Stages
$\begin{aligned} & \text { Presentation } \\ & \text { Practice } \\ & \text { The teacher presents or teaches the new language to the students } \\ & \text { Drilling or less controlled activities }\end{aligned}$
Discussion, role-play or solve the problem, using the language they have just learnt.


specific aspect of language ability oracquisition process, so they are readily used to describe the status of acquisition.

\section{Methods}

The research design was of a $2 \times 1$ across-subjects type with two tasks and one test condition.

\subsection{Subjects}

In September 2014, 65 first-year non-English-majored graduates in 2 classes from Yangtze University participated in this study. Among the 65 subjects, 33 were females and 32 males, average age 22 with Chinese as the main language. Their majors were chemistry, agriculture, plant protection, finance, biological technology. All 65 students who had passed CET4were divided into Experimental group (EG = 33) and Control group (CG = 32) randomly. Their education background, family background, age, and other factors were same, that was to say, their overall learning and cognitive abilities were almost equal. Both EG and CG were taught by the same teacher. Before the experiment, the independent samples t-tests were used to explore whether non-English-majored graduates in EG or CG generated significant differences in oral English performance (Table 3). The survey found that before the experiment, EG and CG showed no significant difference in oral English performance from Accuracy (Task One $(\mathrm{t}=.321, P=.825)$, Task Two $(\mathrm{t}=.417, P=.543))$ to Complexity (Task One $(\mathrm{t}=$ 1.352, $P=.214)$, Task Two $(\mathrm{t}=1.423, P=.143)$ (Table 3$)$.

\subsection{Research Design}

The study was carried out over a period of one semester (September, 2014 to January, 2015). At the beginning of the first semester in the first academic year for non-English-majored graduates' English course, the TBLT methodology in the Experimental group (EG) and 3Ps methodology in the Control group (CG) were implemented by the same teacher who was male, with 15 years' teaching experience. In each group, the teacher and students used the same textbook, that was, Listening and Speaking (published by Foreign Language Teaching and Research Press). Every week, non-English-majored graduates in EG were taught for two hours with the TBLT methodology and non-English-majored graduates in CG were taught for two hours with 3Ps methodology. The experiment lasted for 18 weeks.

\subsection{Instruments}

The instruments used in the study were measures (accuracy, fluency and complexity), two tasks and interviews.

Measures in this study were three: accuracy, fluency and complexity.

Table 3. Pretest on the instruction conditions for two tasks.

\begin{tabular}{|c|c|c|c|c|}
\hline & \multicolumn{2}{|c|}{ Task One } & \multicolumn{2}{|c|}{ Task Two } \\
\hline & $\mathrm{t}$ & $P$ & $\mathrm{t}$ & $P$ \\
\hline \multicolumn{5}{|c|}{ Accuracy } \\
\hline Number of errors per 100 words & .321 & .825 & .417 & .543 \\
\hline \multicolumn{5}{|c|}{ Fluency } \\
\hline Replacements & .834 & .254 & .786 & .357 \\
\hline Reformulations & .763 & .437 & .657 & .543 \\
\hline Pauses & 1.345 & .136 & 1.243 & .236 \\
\hline Repetition & 1.082 & .210 & 1.023 & .125 \\
\hline Number of words per minute & .358 & .673 & .367 & .576 \\
\hline \multicolumn{5}{|c|}{ Complexity } \\
\hline Words per AS-unit & 1.352 & .214 & 1.423 & .143 \\
\hline
\end{tabular}


According to Skehan (1996a), accuracy was the "freedom from error". It was measured in terms of the number of error per 100 words. Mehnert (1998) pointed out that this measure was more sensitive than error-free clauses with learners of relatively low proficiency.

As Skehan notes, "fluency concerns the learners' capacity to mobilize an inter-language system to communicate meanings in real time" (1996a: 46). According to Ellis (2003), the fluency can be measured in terms of the number of pauses(i.e. a break of 2.0 second or longer either within a turn or between turns); the number of repetitions (i.e. immediate and verbatim repetition of a word or phrase); reformulations (phrases or clauses that were repeated with some modification either to syntax, morphology, or word order); replacements (i.e. lexical items that are immediately substituted for another) and number of words per minute(the ratio of total number of words to the time that the particular candidate's spend on the utterance).

Skehan suggested that "Complexity, and its attendant process, restructuring, relates to the stage and elaboration of the underlying inter-language system" (Skehan, 1996a: p. 46). Complexity is often measured in terms of c-unit (Foster \& Skehan, 1996) and t-unit (Foster et al., 2000). But in this study, the author attempted to apply the indicator of words per AS-unit (the Analysis of Speech Unit) (Foster et al., 2000) as the measure of complexity. Foster et al. (2000) pointed out that, in counting the As-unit, some words should be excluded since the inclusion of these data could distort the perception of the nature of the performance.

According to Foster et al. (2000), in this study, when we counted the As-unit, we should exclude one-word minor utterances in the following situation: "Okay, Uhuh, Right, Umm”; when the repetition, replacement or reformulation occurs, the final version was counted as As-unit.

Two tasks used in the study were a problem-solving task and a narrative task, both are required to carry out in English. The choice of these two tasks was based on an analysis of tasks commonly used in current English language textbooks (Listening and Speaking published by Foreign Language Teaching and Research Press, 2010). The first task is a role-play. It belongs to a problem-solving task suggested by Willis's (1996a) task type and similar to the personal task used in the research by Foster and Skehan (1996). The second task is a narrative task. It is similar to the task used in the research by Foster and Skehan (1996), Skehan and Foster (1999) and Mehnert (1998).

Task One: A Tour to Beijing (Unit 2 taken from Listening and Speaking)

Yang is a local tour guide in Beijing. While accompanying her guests to tour round the city of Beijing, she is introducing the top attractions to them. The day's arrangements are as follows. Refer to the information below and have a discussion about the arrangements. One of you is Yang, and the others play the role of the tourists.

Task Two: Describe your own apartment to your partner (Unit 3 taken from Listening and Speaking)

Imagine you have your own apartment (Table 4). Describe it to your partner, who will draw a picture of it with precise ratios of length, width and height.

Interviews: All 33 non-English-majored graduates in EG were interviewed about the TBLT methodology.

\subsection{Data Collection and Analyses}

Before the research experiment (September 2014) and after the experiment (February 2015) two tasks were conducted to compare changes between the two groups of non-English-majored graduates in the TBLT methodology and the 3Ps methodology. In this study, social scientific software SPSS 17.0 was used for statistical analysis to the collected data. In order to find out whether TBLT methodology were superior to 3Psmethodology, comparison of Means was adopted to compare two groups of non-English-majored graduate students' average scores of their pretest and after the experiment on the basis of two samples. And the independent sample T-test was adopted to exanimate if there were significances between EG and CG before the experiment and after the experiment.

Table 4. Details of each room.

\begin{tabular}{cccc}
\hline Room & Size (Sq. m) & Room & Size (Sq. m) \\
\hline Kitchen & 6.8 & Living room & 25.2 \\
Bedroom 1 & 14.2 & Bedroom 2 & 12.6 \\
Dining room & 8.5 & Bathroom 1 & 4.5 \\
Bathroom 2 & 3.6 & Balcony & 11.7 \\
\hline
\end{tabular}




\section{Results}

\subsection{Results from Independent Samples t-Tests}

Independent samples t-tests were used to find out whether any of the instruction conditions (TBLT, 3Ps) generated significant results

As shown in Table 5, we could know the results from independent samples t-tests on the instruction conditions for two tasks between EG and CG. On Task One, only Repetition and the words per AS-unit, which are respectively measures of fluency and complexity, attained significance at the .015 level and at the .01 level, respectively. As for Task Two, Number of errors per 100 words, Replacements, Number of words per minute and Words per AS-unit, these four variables of measurement attained significance at the .05 level.The descriptive statistics on the measures of accuracy, fluency and complexity was showed in Tables 6-8 respectively.

Table 5. Results from independent samples t-tests on the instruction conditions for two tasks.

\begin{tabular}{|c|c|c|c|c|}
\hline & \multicolumn{2}{|c|}{ Task One } & \multicolumn{2}{|c|}{ Task Two } \\
\hline & $\mathrm{t}$ & $P$ & $\mathrm{t}$ & $P$ \\
\hline \multicolumn{5}{|c|}{ Accuracy } \\
\hline Number of errors per 100 words & -.126 & .736 & 4.723 & .013 \\
\hline \multicolumn{5}{|c|}{ Fluency } \\
\hline Replacements & -.213 & .534 & 3.134 & .017 \\
\hline Reformulations & .253 & .135 & 1.252 & .237 \\
\hline Pauses & .315 & .231 & .257 & .325 \\
\hline Repetition & -.321 & .019 & -.327 & .025 \\
\hline Number of words per minute & .225 & .256 & .253 & .019 \\
\hline \multicolumn{5}{|c|}{ Complexity } \\
\hline Words per AS-unit & .345 & .002 & .234 & .013 \\
\hline
\end{tabular}

Table 6. Accuracy and instruction conditions between EG and CG.

\begin{tabular}{cccccc}
\hline & Task One & & & Task Two \\
\cline { 2 - 5 } & & M & S & M & S \\
EG & 2.42 & 4.16 & 4.03 & 5.14 \\
CG & 2.69 & 4.76 & 5.02 & 7.13 \\
\hline
\end{tabular}

M stands for Mean; S stands for Standard Deviation.

Table 7. Fluency and instruction conditions between EG and CG.

\begin{tabular}{|c|c|c|c|c|c|c|c|c|}
\hline \multirow{3}{*}{$\begin{array}{l}\text { Fluency } \\
\text { Items }\end{array}$} & \multicolumn{4}{|c|}{$\mathrm{EG}(\mathrm{N}=33)$} & \multicolumn{4}{|c|}{$\mathrm{CG}(\mathrm{N}=32)$} \\
\hline & \multicolumn{2}{|c|}{ Task One } & \multicolumn{2}{|c|}{ Task Two } & \multicolumn{2}{|c|}{ Task One } & \multicolumn{2}{|c|}{ Task Two } \\
\hline & M & $\mathrm{S}$ & $\mathrm{M}$ & $\mathrm{S}$ & M & $\mathrm{S}$ & M & $\mathrm{S}$ \\
\hline Replacements & 2.81 & 1.01 & 3.13 & 1.23 & 2.12 & 1.34 & 1.25 & .76 \\
\hline Reformulations & 2.91 & 1.53 & 3.14 & .98 & 2.32 & 1.13 & 2.43 & .89 \\
\hline Pauses & .41 & .76 & 1.35 & 1.24 & .18 & .53 & 1.41 & 1.53 \\
\hline Repetition & .21 & .26 & .18 & .23 & .31 & .36 & .32 & .42 \\
\hline Number of words per minute & 156 & 25.26 & 163 & 23.75 & 101 & 31.78 & 104 & 27.86 \\
\hline
\end{tabular}

M stands for Mean; S stands for Standard Deviation. 
Table 8. Complexity and instruction conditions between EG and CG.

\begin{tabular}{|c|c|c|c|c|c|c|c|c|}
\hline \multirow{3}{*}{$\begin{array}{l}\text { Complexity } \\
\text { Items }\end{array}$} & \multicolumn{4}{|c|}{$\mathrm{EG}(\mathrm{N}=33)$} & \multicolumn{4}{|c|}{ CG $(\mathrm{N}=32)$} \\
\hline & \multicolumn{2}{|c|}{ Task One } & \multicolumn{2}{|c|}{ Task Two } & \multicolumn{2}{|c|}{ Task One } & \multicolumn{2}{|c|}{ Task Two } \\
\hline & M & S & M & S & M & S & M & S \\
\hline Words per AS-unit & 6.78 & 1.15 & 7.87 & 1.47 & 4.12 & 1.12 & 5.23 & 1.87 \\
\hline
\end{tabular}

\subsection{Descriptive Statistics for Accuracy Measure}

Question 1, we wanted to investigate that accuracy would be greater under TBLT instruction. Relevant results were presented in Table 6. As shown in Table 6, under TBLT instruction, EG's performance of accuracy from two tasks ((Task One $\mathrm{M}=2.42, \mathrm{~S}=4.16)$, Task Two $(\mathrm{M}=4.03, \mathrm{~S}=4.14)$ ) were better than CG's performance of accuracy from two tasks ((Task One $M=2.69, S=4.76)$, Task Two $(M=5.02, S=7.13)$ ). It suggested that under TBLT instruction, non-English-majored graduates in EG achieved greater accuracy of performance than non-English-majored graduates in CG who were treated in 3Ps instruction.

\subsection{Descriptive Statistics for Fluency Measure}

Question 2, we wanted to investigate that fluency would be greater under TBLT instruction. As shown in Table 7, we could know the results for the fluency in terms of replacement, reformulation, pauses, repetition and number of words perminute. The higher mean scores of replacements, reformulations and number of words per minute were, the more fluency non-English-majored graduates achieved. For two tasks’ performance, non-English-majored graduates in EG, under the TBLT methodology achieved more fluency than non-English-majored graduates in CG under the 3Ps methodology. However, the less mean scores of pauses and repetition were, the more fluency non-English-majored graduates achieved. So, from Table 7, for two tasks’ performance' performance, non-English-majored graduates in EG, under the TBLT methodology achieved more fluency than nonEnglish-majored graduates in CG under the 3Ps methodology.

\subsection{Descriptive Statistics for Complexity Measure}

Question 3, we want to investigate that complexity would be greater under TBLT instruction. As shown in Table 8 , we could know the results for the complexity in terms of words per AS-unit. The higher mean scores of words per were in the two tasks’ performance, the more complexity of speech non-English-majored graduates expressed. From Table 8, for two tasks’ performance, non-English-majored graduates in EG, under the TBLT methodology expressed more complexity in the speech than non-English-majored graduates in CG under the 3Ps methodology.

\subsection{Results of Interviews}

After the experiment, all 33 non-English-majored graduates in EG were interviewed. Among 33 non-Englishmajored graduates, 16 non-English-majored graduates said that under the TBLT methodology, they could speak English more fluent than before the experiment; 10 non-English-majored graduates said that they could speak English more accurate; 5 non-English-majored graduates said that they could speak more complex English sentences in the speech or discussion. However, 2 non-English-majored graduates said that they did not realize the changes in the aspects of accuracy, fluency and complexity for their oral English under the TBLT methodology because their English foundation was not good, they could not understand what their partners' meaning and they were afraid to speak English with other classmates.

\section{Discussion}

This study focus on the effect of TBLT as a whole on non-English-majored graduates performance. The results show that TBLT has a positive effect on non-English-majored graduates' performance. But the degree of effect varied according to the variables of the instruments and the goal of performance.

First, from Table 6, we can know that TBLT instruction promoted greater accuracy of performance than3Ps did. Under the TBLT methodology, non-English-majored graduates have tasks to do and communicate with 
other people to complete the tasks. They want to express their accurate meanings in doing tasks, they need improve their pronunciation more accurate, choosing more accurate words for the meaning for words understood by their partners to complete tasks. During the process of completing tasks, non-English-majored graduates in EG promote their accuracy, then they have greater accuracy of performance.

Second, EG produced a much more fluent performance. Learning through tasks is seen to transition through phases with an initial trigger, signal, response and follow-up (Pica, Holliday, Lewis, Berducci, \& Newman, 1991), as meaning is negotiated. EG, under the TBLT methodology, need to complete the tasks. During completing tasks, non-English-majored graduates in EG need the partners to cooperate to complete the tasks, they have to negotiate the meanings with partners as fluent as possible in order to complete the tasks as soon as possible. If the partner could not understand his or her meaning in completing tasks, he or she need to modify his or her meaning by the method of replacement or reformulation, so under the TBLT methodology, EG have more chances to improve their spoken English to let them speak English more fluent.

Final, as for complexity, the TBLT instruction promoted a relatively even level of performance across the tasks. On both tasks, EG produced more complex language performance than CG did. In doing tasks, non-English-majored graduates in EG may develop some strategies to deal with different kinds of tasks, they may develop their complexity in spoken English to complete the different kinds of tasks and, at the same time, they develop their intelligence in doing tasks.

However, according to the results of interviews with non-English-majored graduates in EG, among 33 nonEnglish-majored graduates, 2 subjects in EG said that they did not realize the changes in the aspects of accuracy, fluency and complexity for their oral English under the TBLT methodology. The TBLT methodology is not effective to all subjects in EG, especially some non-English-majored graduates with poor English foundation in listening and speaking. In TBLT, effective teachers design tasks that take into consideration the learning styles, interests, and prior knowledge of their students (Adjei-Barrett, 2013). We need think about a lot of things such as the learning styles, interests, and prior knowledge of their students when we adopt the TBLT methodology.

\section{Limitations and Suggestions for Further Research}

Though the present study has provided a comparatively detailed description of the task-based language teaching approach among some first-year non-English-majored graduate students, there are still some limitations of the study. Having the limitations in mind, suggestions for further research, therefore, can be put forward at the same time in order to achieve a lot thorough understanding of the task-based language teaching approach to nonEnglish-majored graduates in oral English instruction.

Firstly, being time limitation (only a term) and other practical restrictions such as the subjects in the study consisted of only on-English-majored graduate students in one university need to be broadened in further research.

Secondly, the instruments used to investigate non-English-majored graduate oral English instruction involve structured questionnaire and tests. The study would be much better, if it were combined with other instruments such as observation, verbal report. More instruments should be used in investigation in further research.

Finally, the task-based language teaching approach applied in non-English-majored graduate oral English can improve non-English-majored graduate students' English output ability in speaking, but the task-based language teaching approach also works for other subjects such as undergraduate students, we need further research.

Despite of the restraints of the study, it is hoped that it can offer some guidelines for further research on the task-based language teaching in oral English teaching.

\section{Conclusion}

TBLT is a pedagogy premised on the belief that "the most effective way to teach a language is by engaging learners in real language use" through teacher designed tasks that "require learners to use the language for themselves" (Willis \& Willis, 2012: p. 1). The task-based language teaching and learning method is a kind of language teaching and learning method existed for many years. The present study investigated the effects of task-based language teaching (TBLT) and learning on non-English-majored graduates' oral performance through two tasks in a comparative way. There were 65 first-year non-English-majored graduates from Yangtze University participated in this study. In this study, the experimental group was treated under the TBLT instruction and the control group received the treatment of 3Ps instruction through one semester. At the end of the 
semester, two tasks were used to elicit the participants' performance. By comparing the experimental effects of TBLT on non-English-majored graduates' oral performance of accuracy, fluency and complexity with that of 3Ps instruction, the author drew a conclusion that TBLT methodology was superior to that of 3Ps.

\section{References}

Adjei-Barrett, A. (2013). Task-Based Interactions in Spanish as a Foreign Language Classroom. Doctoral Dissertation. Retrieved from ProQuest. (Publication No. 3565710).

Baker, J., \& Westrup, H. (2003). Essential Speaking Skills: A Handbook for English Language Teachers. London: Continuum.

Dettori \& Giuliana (2011). Task-Based Language Learning and Teaching with Technology. British Journal of Educational Technology, 42, E114-E115.

Ellis, R. (2003). Task-Based Language Learning and Teaching. Oxford: Oxford University Press.

Foster, P., \& Skehan, P. (1996). The Influence of Planning and Task Type on Second Language Performance. Studies in Second Language Acquisition, 18, 299-324. http://dx.doi.org/10.1017/S0272263100015047

Foster, P., Tonkyn, A., \& Wigglesworth, G. (2000). Measuring Spoken Language: A Unit for All Reasons. Applied Linguistics, 21, 354-75. http://dx.doi.org/10.1093/applin/21.3.354

Huang, J. H. (2010). Grammar Instruction for Adult English Language Learners: A Task-Based Learning Framework. Journal of Adult Education, 39, 29-37.

Ji, K. L. (2014). Effects of a Task-Based Approach to Public Speaking Instruction. Chinese Journal of Applied Linguistics, 37, 21-32.

Margaret, R. (2014). Task-Based Language Teaching and Expansive Learning Theory. TESL Canada Journal, 31, 187-198.

Mehnert, U. (1998). The Effects of Different Lengths of Time for Planning on Second Language Performance. Studies in Second Language Acquisition, 20, 83-108. http://dx.doi.org/10.1017/S0272263198001041

Nunan, D. (1989). Designing Tasks for the Communicative Classroom. Cambridge: Cambridge University Press.

Nunan, D. (2004). Task-Based Language Teaching. Cambridge: Cambridge University Press. http://dx.doi.org/10.1017/CBO9780511667336

Pica, T., Holliday, L., Lewis, N., Berducci, D., \& Newman, J. (1991). Language Learning through Interaction: What Role Does Gender Play? Studies in Second Language Acquisition, 13, 343-376. http://dx.doi.org/10.1017/S0272263100010020

Skehan, P. (1996a). A Framework for the Implementation of Task-Based Instruction. Applied Linguistics, 17, $38-62$. http://dx.doi.org/10.1093/applin/17.1.38

Skehan, P. (1996b). Second Language Acquisition Research and Task-Based Instruction. In J. Willis, \& D. Willis (Eds.), Challenge and Change in Language Teaching (pp. 17-30). Oxford: Macmillan Heinemann.

Skehan, P. (1998). A Cognitive Approach to Language Learning. Oxford: Oxford University Press.

Skehan, P., \& Foster, P. (1999). The Influence of Task Structure and Processing Conditions on Narrative Retellings. Language Learning, 49, 93-120. http://dx.doi.org/10.1111/1467-9922.00071

Sun, Z. C. (2015). A Tentative Study on the Task-Based Teaching of Writing to English Majors in Chinese Settings. English Language Teaching, 8, 71-79.

Willis, D. (1996b). Accuracy, Fluency and Conformity. In J. Willis, \& D.Willis (Eds.), Challenge and Change in Language Teaching (p. 45). Oxford: Macmillan Heineman.

Willis, D., \& Willis, J. (2012). Doing Task-Based Teaching. Oxford: Oxford University Press. (Original work published 2007)

Willis, J. (1996a). A Framework for Task-Based Learning. Addison, TX: Wesley Longman Limited. 